\title{
Decadal trends in aerosol chemical composition at Barrow, Alaska: 1976-2008
}

\author{
P. K. Quinn ${ }^{1}$, T. S. Bates ${ }^{1}$, K. Schulz ${ }^{1}$, and G. E. Shaw ${ }^{2}$ \\ ${ }^{1}$ NOAA PMEL, 7600 Sand Point Way NE, Seattle, WA 98115, USA \\ ${ }^{2}$ University of Alaska, 903 Koyukuk Dr., Fairbanks, AK 99775, USA
}

Received: 26 August 2009 - Published in Atmos. Chem. Phys. Discuss.: 10 September 2009

Revised: 6 November 2009 - Accepted: 13 November 2009 - Published: 23 November 2009

\begin{abstract}
Aerosol measurements at Barrow, Alaska during the past 30 years have identified the long range transport of pollution associated with Arctic Haze as well as ocean-derived aerosols of more local origin. Here, we focus on measurements of aerosol chemical composition to assess (1) trends in Arctic Haze aerosol and implications for source regions, (2) the interaction between pollution-derived and ocean-derived aerosols and the resulting impacts on the chemistry of the Arctic boundary layer, and (3) the response of aerosols to a changing climate. Aerosol chemical composition measured at Barrow, AK during the Arctic haze season is compared for the years 1976-1977 and 1997-2008. Based on these two data sets, concentrations of non-sea salt (nss) sulfate $\left(\mathrm{SO}_{4}^{=}\right)$and non-crustal (nc) vanadium $(\mathrm{V})$ have decreased by about $60 \%$ over this 30 year period. Consistency in the ratios of $\mathrm{nss} \mathrm{SO}_{4}^{=} / \mathrm{ncV}$ and nc manganese $(\mathrm{Mn}) / \mathrm{ncV}$ between the two data sets indicates that, although emissions have decreased in the source regions, the source regions have remained the same over this time period. The measurements from 1997-2008 indicate that, during the haze season, the nss $\mathrm{SO}_{4}^{=}$aerosol at Barrow is becoming less neutralized by ammonium $\left(\mathrm{NH}_{4}^{+}\right)$yielding an increasing sea salt aerosol chloride $\left(\mathrm{Cl}^{-}\right)$deficit. The expected consequence is an increase in the release of $\mathrm{Cl}$ atoms to the atmosphere and a change in the lifetime of volatile organic compounds (VOCs) including methane. In addition, summertime concentrations of biogenically-derived methanesulfonate $\left(\mathrm{MSA}^{-}\right)$and
\end{abstract}

Correspondence to: P. K. Quinn (patricia.k.quinn@noaa.gov) nss $\mathrm{SO}_{4}^{=}$are increasing at a rate of 12 and $8 \%$ per year, respectively. Further research is required to assess the environmental factors behind the increasing concentrations of biogenic aerosol.

\section{Introduction}

Arctic haze, defined here as the occurrence each winter and spring of increased aerosol concentrations and decreased visibility, was reported as early as the late 1800s (Nordenskiöld, 1883; Garrett and Verzella, 2008). It was not until the late 1970s, however, that it became possible to determine through chemical analyses that the haze was anthropogenic in origin and was a result of long range transport from the northern hemisphere mid-latitudes. These early studies used ratios of tracer species to identify likely source regions with the assumption that there are regional differences in pollution aerosol resulting from differences in combusted fuel, transportation, and industrial activities (e.g. Rahn and Shaw, 1980; Rahn and McCaffrey, 1980). The ratio of non-crustal $(\mathrm{nc})$ manganese $(\mathrm{Mn})$ to nc vanadium $(\mathrm{V})$ was shown to be a useful tracer of regional sources.

$\mathrm{NcV}$ is a tracer of mid-latitude anthropogenic activity; its most significant pollution source is combustion of heavy residual oil (Zoller et al., 1973) which is too viscous to be used at cold temperatures. NcMn in the atmosphere results from a wider variety of anthropogenic activities including iron, steel, and ferro-alloy manufacturing; coal combustion; oil combustion; and mining (Pacyna et al., 1984). Rahn (1981) reported that the wintertime ncMn to $\mathrm{ncV}$ ratio

Published by Copernicus Publications on behalf of the European Geosciences Union. 
was a factor of 5 higher in aerosol originating from Europe than from the northeast U.S. The higher ratios measured in Europe were attributed to the abundance of ferrous and nonferrous industries and the lower ratios in the NE US were attributed to the residual oil burned for residential heating in the winter. Based on these regional values and taking into account the expected decrease in the ratio with transport due to the different size distributions of Mn and V, Rahn (1981) concluded that Europe was a more significant source region for Arctic aerosol than the NE US. Furthermore, compared to Norwegian Arctic aerosol, N. American Arctic aerosol was more influenced by a source in addition to Europe. It was suggested that the additional source was the central former Soviet Union. Raatz and Shaw (1984) confirmed that central Eurasian sources dominated the aerosol at Barrow during the winter in a follow up analysis that combined the 1976 to 1980 Barrow time series of $\mathrm{ncMn}$ and $\mathrm{ncV}$ concentrations with the synoptic conditions existing at the source regions and in the Arctic. Expanding the tracer analysis to seven elements, Lowenthal and Rahn (1985) determined that $70 \%$ of most tracer elements at Barrow came from the former Soviet Union during the winter of 1979-1980 and 25\% came from Europe.

Non-seasalt (nss) sulfate $\left(\mathrm{SO}_{4}^{=}\right)$makes up a large but variable fraction of Arctic Haze aerosol (Quinn et al., 2007). During the winter and early spring, fossil fuel combustion in distant source regions is the primary source of $\mathrm{nss}^{-} \mathrm{SO}_{4}^{=}$since biological activity is at a minimum (e.g. Ferek et al., 1995). Rahn and McCaffrey (1980) compared wintertime nss $\mathrm{SO}_{4}^{=}$ to $\mathrm{ncV}$ ratios at Arctic and non-Arctic sites and found that ratios within the Arctic were over an order of magnitude larger than those measured in mid-latitude source regions. They attributed the higher Arctic ratios to oxidation of mid-latitude $\mathrm{SO}_{2}$ while enroute to Barrow resulting in an aged version of mid-latitude aerosol.

During the summer, the oxidation of biogenicallyproduced dimethylsulfide yields aerosol nss $\mathrm{SO}_{4}^{=}$and methanesulfonate $\left(\mathrm{MSA}^{-}\right)$. Concentrations of $\mathrm{MSA}^{-}$due to local production peak from May to September as the ice recedes and phytoplankton productivity in surface waters begins (e.g. Li et al., 1993; Quinn et al., 2002). In addition, there is a rapid release of DMS from the ice into surface waters and from under the ice into the atmosphere following the ice break up (Levasseur et al., 1994; Ferek et al., 1995).

In this paper we compare concentrations of $\mathrm{ncMn}, \mathrm{ncV}$, nss $\mathrm{SO}_{4}^{\bar{y}}$, and ratios of tracer species measured at Barrow over the past decade to those measured during the late 1970s to assess changes in the concentrations and sources of Arctic Haze aerosol over the past 30 years. In addition, we present trends in summertime nss $\mathrm{SO}_{4}^{=}$and $\mathrm{MSA}^{-}$and changes in the composition of the inorganic fraction of the aerosol that have occurred at Barrow over the past decade and the implications associated with this changing aerosol composition.

\section{Measurements}

The 1976-1977 measurements were based on High-Volume samples collected over 3 to 7 days with subsequent analysis by instrumental neutron activation (Rahn and McCaffrey, 1980). Sample collection during the 1997-2008 period was done with a Berner-type multijet cascade impactor with an aerodynamic $D_{50}$ cutoff diameter of $1 \mu \mathrm{m}$. Samples collected between 1997 and 2008 were analyzed for inorganic ions $\left(\mathrm{Na}^{+}, \mathrm{NH}_{4}^{+}, \mathrm{Cl}^{-}, \mathrm{SO}_{4}^{=}\right.$, and $\left.\mathrm{MSA}^{-}\right)$by ion chromatography (Quinn et al., 1998). Samples collected between 2003 and 2008 were analyzed for trace elements (including $\mathrm{Al}, \mathrm{V}$, and $\mathrm{Mn}$ ) by thin-film X-ray primary and secondary emission spectrometry (Bates et al., 2004). Sampling during the 19972008 period was sector controlled such that real-time wind speed and direction were used to exclude data from the locally polluted sector $\left(130\right.$ to $\left.360^{\circ}\right)$. More details of the sample inlet, sampling procedures, and chemical analyses can be found in Delene and Ogren (2002) and Quinn et al. (2002). Given that the species considered here occur primarily in the submicrometer size range, the sampling methods used for the two different data sets should not affect the results.

Sea salt $\mathrm{SO}_{4}^{=}$concentrations were calculated from measured $\mathrm{Na}^{+}$concentrations and the mass ratio of sulfate to

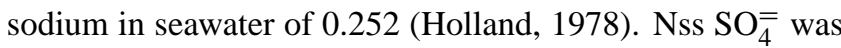
calculated from the difference between the total and sea salt components. Crustal V and Mn concentrations were calculated from the mass ratio of the element to $\mathrm{Al}$ in crustal material using the values of Mason (1966) (0.00166 for $\mathrm{V}$ and 0.0117 for $\mathrm{Mn}$ ). $\mathrm{NcV}$ and $\mathrm{ncMn}$ were calculated from the difference of the total and crustal V and Mn concentrations.

The existence of a monotonic increasing or decreasing trend in the time series was tested with the nonparametric Mann-Kendall test (Gilbert, 1987). The estimate for the slope of a linear trend was calculated with the nonparametric Sen's method (Sen, 1968). Trends are reported for significance levels, $\alpha$, of $0.01,0.05$, and 0.1 where a significance level of $<0.1$ indicates that the probability of no trend is $10 \%$ or less. No $\alpha$ is reported if the significance level is $>0.1$. The reported significance levels do not take into account uncertainties associated with measured concentrations or interannual variability. Hence, significance levels may be higher than those reported for the trends derived from the combined 1976-1977 and 1997-2008 data sets.

The haze season is defined throughout as January to April and is based on the months during which Arctic haze is most pronounced. Summer is defined here as July to September as these are the months with relatively high biogenic activity (based on MSA concentrations) and low anthropogenic impact (based on $\mathrm{nss}^{\mathrm{SO}}=$ concentrations). 

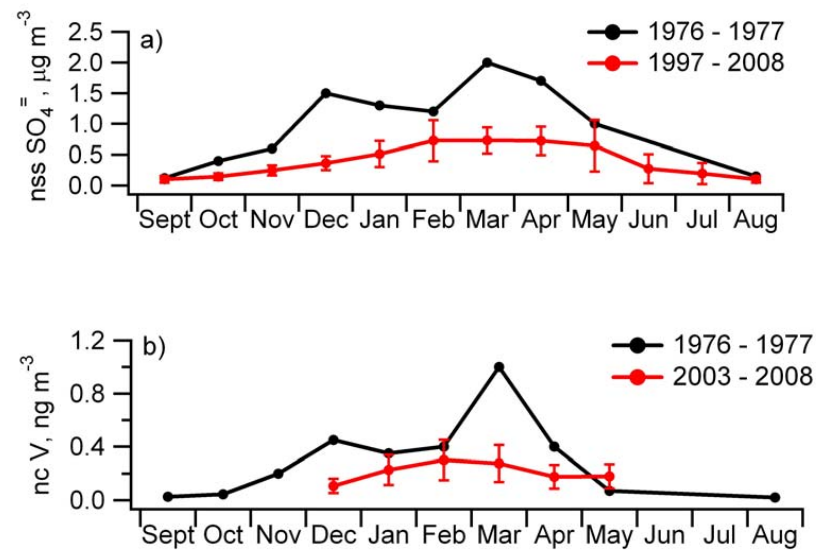

Fig. 1. Monthly averaged values from 1976-1977 and 1997-2008 for (a) $\mathrm{nss} \mathrm{SO}_{4}^{=}$and (b) ncV. The 1976-1977 data are from Rahn and McCaffrey (1980). Vertical bars for the 1997-2008 data here and throughout are the $1 \sigma$ standard deviation of the monthly average.

\section{Results and discussion}

\subsection{Non-seasalt $\mathrm{SO}_{4}^{=}$and non-crustal $\mathrm{V}$ at Barrow}

Rahn and McCaffrey (1980) published the first year-round measurements of nss $\mathrm{SO}_{4}^{=}$and $\mathrm{ncV}$ at Barrow, AK covering the period of September 1976 to September 1977. These measurements revealed the seasonality of Arctic Haze with an increase in the concentration of both species in the fall, a maximum in the winter and early spring, and a decrease in late spring. More recent measurements of nss $\mathrm{SO}_{4}^{=}$ (October 1997 to April 2008) and ncV (January 2005 to April 2008) reveal a similar seasonal cycle but overall lower concentrations (Fig. 1). The broad winter to early spring maximum in nss $\mathrm{SO}_{4}^{=}$has been attributed to an initial transport of anthropogenic nss $\mathrm{SO}_{4}^{=}$produced in mid-latitude source regions and the transport and subsequent oxidation of $\mathrm{SO}_{2}$ to $\mathrm{SO}_{4}^{=}$as light levels increase enroute to and within the Arctic itself (Barrie and Hoff, 1984). The nss $\mathrm{SO}_{4}^{=}$December maximum apparent in the earlier data set but not in the latter may be due to inter-annual variability or to a change in emissions and/or the $\mathrm{SO}_{2}$ oxidation efficiency in the source regions.

Combining the 1976-1977 and 1997-2008 data sets and performing a linear regression of concentrations averaged over the haze season versus year reveals a decrease of about $60 \%$ over the past 30 years for both $\mathrm{nss} \mathrm{SO}_{4}^{=}$and ncV (Fig. $2 \mathrm{a}$ and $b$ ). This change corresponds to a $2 \%$ decrease per year. The similarity in the haze season $\mathrm{nss}^{\mathrm{SO}}=/ \mathrm{ncV}$ ratio for the two data sets is shown in Fig. 2c. The reported value for 1976-1977 was 3 while haze season values between 2003 and 2008 ranged from 2.9 to 4.2. For comparison, wintertime values reported for the NE US and Europe are much lower at 0.28 and 0.26, respectively (Rahn and McCaffrey, 1980).

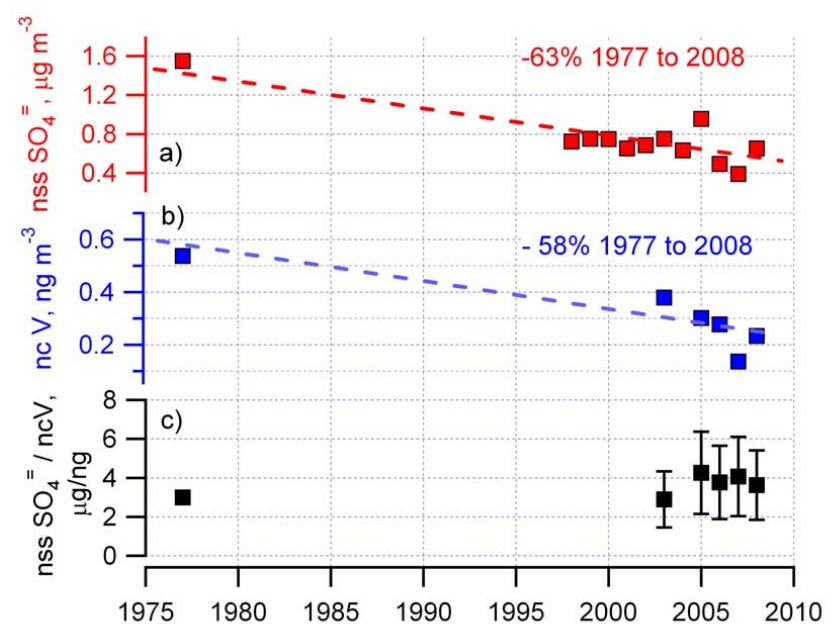

Fig. 2. Concentrations of (a) nss $\mathrm{SO}_{4}^{=}$and (b) $\mathrm{ncV}$ averaged over the haze season (January-April) and (c) the $\mathrm{nss}^{\mathrm{S}}=\mathrm{n}$ to $\mathrm{ncV}$ ratio. The 1976-1977 data are from Rahn and McCaffrey (1980).

The stability in the nss $\mathrm{SO}_{4}^{=} / \mathrm{ncV}$ ratio indicates that the same source regions are being measured today as 30 years ago and that the decrease in the concentrations of nss $\mathrm{SO}_{4}^{=}$and $\mathrm{ncV}$ is, in large part, a result of a decrease in emissions in the source regions. Hence, this result supports time series estimates of sulfur emissions that report a decline globally and, in particular, for countries that are known source regions to the Arctic, from the 1970s through 2000 (e.g. Berge et al., 1999; Erisman et al., 2003; Stern, 2005).

Changes in the frequency of transport of pollution to the Arctic and removal during transport may also have influenced measured concentrations at Barrow. Strong transport into the Arctic from Eurasia during winter is due, in part, to the persistence of the Siberian high (Barrie, 1986; Christensen, 1997). Weakening of the Siberian High over the past quarter century (Gong and Ho, 2002) may be contributing to less pollution reaching the Arctic from Eurasia. Determining the relative importance of transport frequency and removal processes will require further studies that combine modeled transport and removal with measured concentrations and known changes in emissions.

\subsection{Non-crustal Mn and $\mathrm{V}$ at Barrow}

Rahn (1981) reported ncMn/ncV ratios greater than 1 for the N. American Arctic based on measurements made during the winter and spring of 1976-1978. Values reported for Barrow and Mould Bay, NWT averaged around 2 and 1.5, respectively. The $n c M n / n c V$ ratio averaged over the haze season at Barrow between 2003 and 2008 ranged from 1.3 to 2.3. Recreating the ncV vs. ncMn scatter plot of Rahn (1981) and adding the 2003-2008 data show that the recent Barrow measurements agree with the unique N. American Arctic data from 30 years ago (Fig. 3). The $\mathrm{ncMn} / \mathrm{ncV}$ ratio measured 


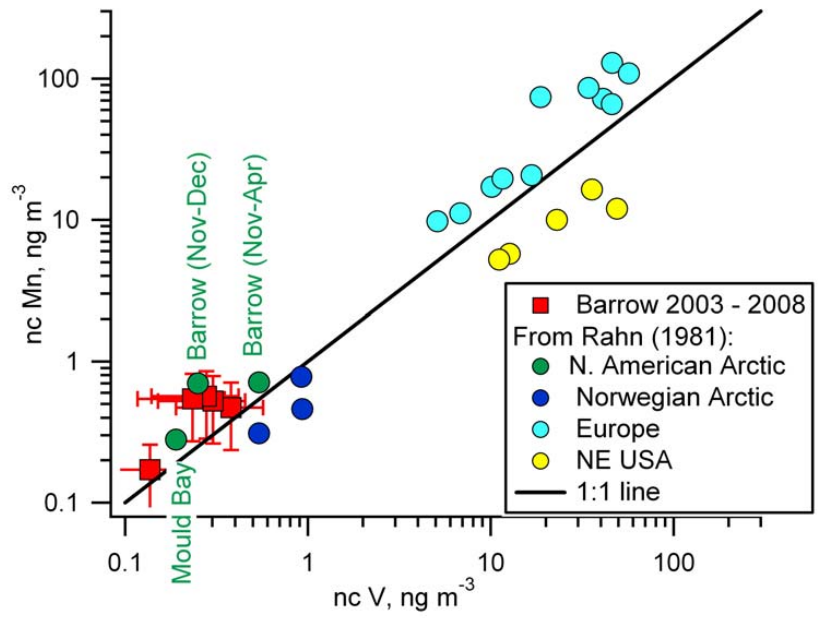

Fig. 3. A comparison of $\mathrm{ncV}$ versus ncMn from Barrow (20032008) with values previously reported by Rahn (1981) for the North American Arctic (Barrow and Mould Bay), the Norwegian Arctic (Bear Island and Spitsbergen), Europe, and the N. E. US.

at Barrow has remained in the same range and distinct from the Norwegian Arctic and the NE US. Again, these results indicate that emissions in the source regions to the Arctic have decreased over the past 3 decades but the source regions themselves have not changed.

\section{3 $\mathrm{Cl}^{-}$deficit at Barrow}

Measurements of the concentration of inorganic ions in submicrometer aerosol particles have been made continuously at Barrow since the fall of 1997 allowing for the observation of changes in aerosol composition during both the haze season and during summer. Over the past decade, haze season concentrations of $\mathrm{nss} \mathrm{SO}_{4}^{=}$have decreased by about $2 \%$ per year (Fig. 4a) and $\mathrm{NH}_{4}^{+}$concentrations have decreased at a rate of $6 \%$ per year. As a result, the $\mathrm{NH}_{4}^{+} / \mathrm{nss}^{=} \mathrm{SO}_{4}^{=}$molar ratio has decreased by $6.4 \%$ per year $(\alpha=0.01)$ (Fig. $4 \mathrm{c}$ ). Reasons for the different rates of decrease in the observed concentrations for the two species are not clear. There is observational evidence that emissions of $\mathrm{NH}_{3}$ and $\mathrm{SO}_{2}$ are decreasing in source regions to the Arctic (e.g. Erisman et al., 1999; Berge et al., 1999). However, emissions for the Russian Federation and European Communities as used in EMEP Models indicate that $\mathrm{SO}_{\mathrm{x}}$ emissions decreased at a higher rate between 1997 and 2008 than $\mathrm{NH}_{3}$ emissions (Gauss et al., 2008a, b). Assessing the concentration decreases observed at Barrow will require not only accurate emission data for $\mathrm{NH}_{3}$ and $\mathrm{SO}_{\mathrm{x}}$ but also quantification of the reaction rate of gas phase $\mathrm{NH}_{3}$ with acidic sulfate aerosol and removal of $\mathrm{NH}_{4}^{+}$and $\mathrm{SO}_{4}^{=}$ near the source region and enroute to Barrow.

The decreasing $\mathrm{NH}_{4}^{+} / \mathrm{nss}_{4} \mathrm{SO}_{4}^{=}$molar ratio results in an increasingly acidic anthropogenic aerosol that is available to react with sea salt aerosol in the Barrow boundary layer.

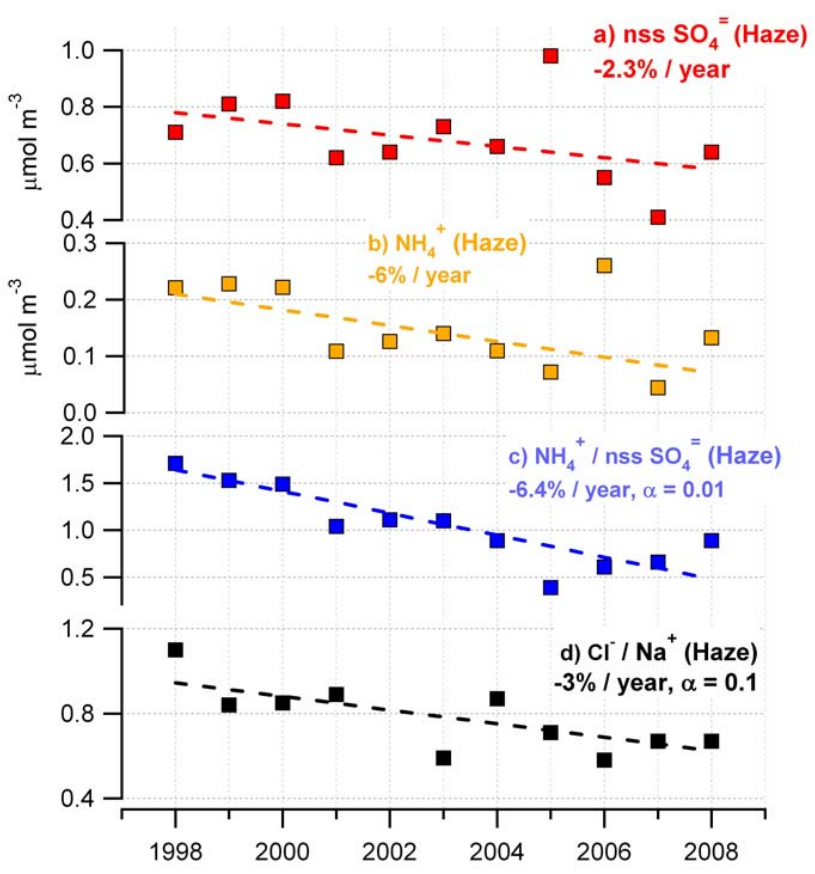

Fig. 4. Values of (a) nss $\mathrm{SO}_{4}^{=}$, (b) $\mathrm{NH}_{4}^{+}$, (c), $\mathrm{NH}_{4}^{+} / \mathrm{nss} \mathrm{SO}_{4}^{=}$molar ratio and (d) $\mathrm{Cl}^{-} / \mathrm{Na}^{+}$molar ratio averaged over the haze season (January-April) at Barrow. Lines indicate the Sen's slope estimates. $\alpha$ indicates the significance level of the trend.

Figure $4 \mathrm{~d}$ shows a decrease in the $\mathrm{Cl}^{-}$to $\mathrm{Na}^{+}$ratio, or an increase in $\mathrm{Cl}^{-}$depletion from the sea salt aerosol, of $3 \%$ per year $(\alpha=0.1)$. The correspondence of these two trends suggests that the less neutralized $\mathrm{nss}^{\mathrm{SO}}=\overline{4}$ aerosol yields an increase in the $\mathrm{HCl}$ displacement from the sea salt aerosol. The consequent increase in concentration of $\mathrm{Cl}$ atoms, even at low concentrations, can reduce the lifetime of volatile organic compounds (VOCs) including $\mathrm{CH}_{4}$ (Platt et al., 2004), a potent greenhouse gas, and impact reactions that destroy or produce $\mathrm{O}_{3}$ (Knipping et al., 2003). In addition to $\mathrm{HCl}$, there is evidence that highly reactive gases such as $\mathrm{Cl}_{2}, \mathrm{HOCl}$, and $\mathrm{ClNO}_{2}$ may also volatilize from sea salt aerosol (e.g. Pszenny et al., 1993). Hence, this result has potentially important implications for the $\mathrm{Cl}$ photochemistry occurring in the nearsurface Arctic atmosphere (Keene et al., 1998).

In contrast to the haze season, the summertime aerosol at Barrow is much less impacted by industrial pollutants from long range transport and more influenced by biogenic sources (e.g. Quinn et al., 2002). Concentrations of $\mathrm{MSA}^{-}$, which is derived solely from the oxidation of biogenically produced DMS, begin to increase in April, peak in May through September, and decrease dramatically in October. The elevated concentrations of $\mathrm{MSA}^{-}$in late spring may be due to long range transport from source regions in the North $\mathrm{Pa}$ cific (Li et al., 1993). By late June, local biogenic production of $\mathrm{MSA}^{-}$and nss $\mathrm{SO}_{4}^{=}$becomes important as the ice melt begins and phytoplankton productivity in surface waters 
increases. O'Dwyer et al. (2000) compared $\mathrm{MSA}^{-}$preserved in a Svalbard ice core with sea surface temperature (SST) and sea-ice extent over the period between 1920 and 1996. They found high $\mathrm{MSA}^{-}$concentrations were associated with warm SST and reduced sea-ice extent and suggested that $\mathrm{MSA}^{-}$ concentrations in ice cores may be useful as a proxy for past climate.

The correspondence between $\mathrm{MSA}^{-}$and past climate may also be relevant for current and future changes in the Arctic. Over the past decade, there has been an increase in summertime concentrations of $\mathrm{MSA}^{-}$of $12 \%$ per year $(\alpha=0.1)$ and of nss $\mathrm{SO}_{4}^{=}$of $8 \%$ per year $(\alpha=0.05)$ (Fig. 5a and b). Although it is beyond the scope of this paper to attribute these increasing trends to particular factors, the ice core results suggest that they may be due to recent decreases in sea-ice cover and increases in mean sea surface temperature (SST). Further work is required to link the observed trends at Barrow to changing environmental factors. Particle number concentrations are highest at Barrow and other surface Arctic sites during the summer (Quinn et al., 2002; Engvall et al., 2008) suggesting a link between biogenic activity and enhanced particle production. The climatic importance of the biogenically produced particles at Barrow, in terms of their ability to act as cloud condensation nuclei, is yet to be determined.

\section{Conclusions}

A comparison of the aerosol chemical composition at Barrow, AK measured during the winter and spring of 19761977 and 1997-2008 indicates that the mass concentrations of species contributing to Arctic haze have decreased markedly over the past 30 years. In addition, it appears that while emissions have decreased, the source regions of Arctic haze are the same now as 3 decades ago. Further work is required to assess additional factors that may be contributing to decreasing aerosol concentrations observed at Barrow during the Arctic haze season including changes in the frequency of transport of pollution to the Arctic and removal during transport. In addition, accurate emission data for all species that undergo long range transport to the Arctic during the haze season would improve the understanding of the observed trends.

Measurements of concentrations of aerosol inorganic ions at Barrow over the past decade reveal an increase in the $\mathrm{Cl}^{-}$ deficit associated with sea salt aerosol. This increased release of $\mathrm{HCl}$ and perhaps other additional reactive $\mathrm{Cl}$-containing gases has implications for halogen chemistry in near surface air at Barrow including changes in the lifetimes of ozone, methane, DMS, and other species. In addition, summertime concentrations of $\mathrm{MSA}^{-}$and $\mathrm{nss}_{4}^{=}$at Barrow have increased over the past decade. These increasing trends may be a result of a changing climate in the Arctic (e.g. warmer SST and reduced sea ice extent) and, if maintained, may affect the radiative balance within the Arctic through enhanced

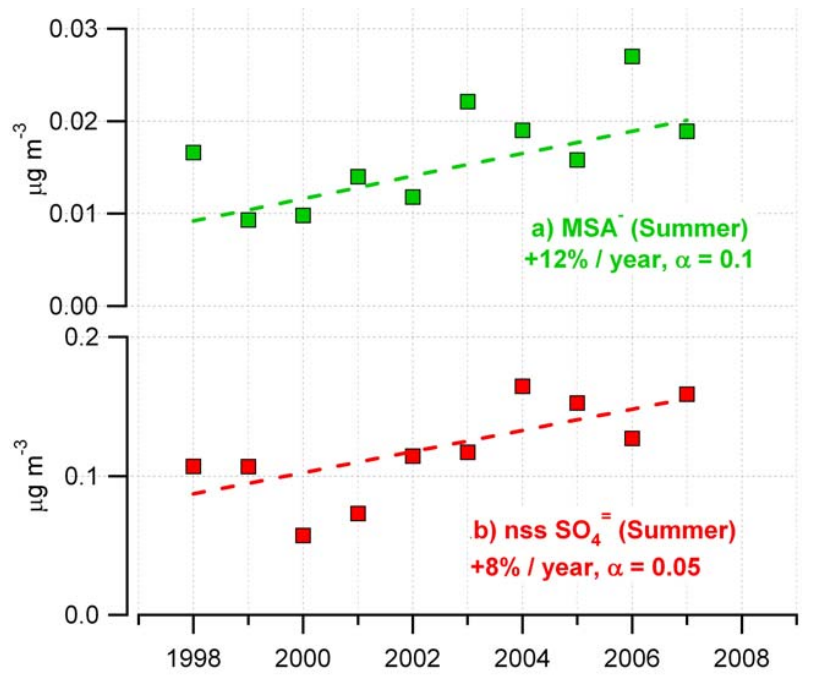

Fig. 5. Values of (a) $\mathrm{MSA}^{-}$and (b) nss $\mathrm{SO}_{4}^{=}$averaged over the summertime (July-September) at Barrow. Lines indicate the Sen's slope estimates. $\alpha$ indicates the significance level of the trend.

particle production. Further work is required to link the observed trends in summer time aerosol at Barrow to changing environmental factors.

Acknowledgements. We thank Dan Endres and other members of the support staff at Barrow for their help in collecting samples and the Aerosols Group at NOAA's Global Monitoring Division for maintaining the sampling system. This work was supported by the NOAA Climate Program Office. This is PMEL paper contribution 3437.

Edited by: A. Stohl

\section{References}

Barrie, L. A.: Arctic air pollution: An overview of current knowledge, Atmos. Environ., 20, 643-663, 1986.

Barrie, L. A. and Hoff, R. M.: The oxidation rate and residence time of sulphur dioxide in the Arctic atmosphere, Atmos. Environ., 18, 2711-2722, 1984.

Bates, T.S., P.K. Quinn, D.J. Coffman, D.S. Covert, T.L. Miller, and J.E. Johnson, Marine boundary layer dust and pollutant transport associated with the passage of a frontal system over eastern Asia, J. Geophys. Res., 109, D19S19, doi:10.1029/2003JD004094, 2004.

Berge, E., Bartnicki, J., Olendrzynski, K., and Tsyro, S. G.: Longterm trends in emissions and transboundary transport of acidifying air pollution in Europe, J. Environ. Manage., 57, 31-50, 1999.

Christensen, J. H.: The Danish eulerian hemispheric model-a three dimensional air pollution model used for the Arctic, Atmos. Environ., 31, 4169-4191, 1997.

Delene, D. J. and Ogren, J. A.: Variability of aerosol optical properties at four North American surface monitoring sites, J. Atmos. Sci., 59(6), 1135-1150, 2002. 
Engvall, A.-C., Krejci, R., Ström, J., Treffeisen, R., Scheele, R., Hermansen, O., and Paatero, J.: Changes in aerosol properties during spring-summer period in the Arctic troposphere, Atmos. Chem. Phys., 8, 445-462, 2008, http://www.atmos-chem-phys.net/8/445/2008/.

Erisman, J. W., Grennfelt, P., and Sutton, M.: The European perspective on nitrogen emission and deposition, Environ. Int., 29, 311-325, 2003.

Ferek, R. J., Hobbs, P. V., Radke, L. F., Herring, J. A., Sturges, W. T., and Cota, G. F.: Dimethyl sulfide in the arctic atmosphere, J. Geophys. Res., 100, 26093-26104, 1995.

Garrett, T. J. and Verzella, L. L.: An evolving history of Arctic aerosols, B. Am. Meteorol. Soc., 89, 299-302, 2008.

Gauss, M., Nyiri, A., and Klein, H.: Transboundary air pollution by main pollutants $\left(\mathrm{S}, \mathrm{N}, \mathrm{O}_{3}\right)$ and PM: The Russian Federation, MSC-W Data Note 1, 2008a.

Gauss, M., Nyiri, A., and Klein, H.: Transboundary air pollution by main pollutants $\left(\mathrm{S}, \mathrm{N}, \mathrm{O}_{3}\right)$ and PM: The European Community, MSC-W Data Note 1, 2008b.

Gilbert, R. O.: Statistical Methods for Environmental Pollution Monitoring, Van Nostrand Reinhold, New York, 1987.

Gong, D. Y. and Ho, C. H.: The Siberian High and climate change over middle to high latitude Asia, Theor. Appl. Climatol., 72, $1-9,2002$.

Holland, J. D.: The Chemistry of the Atmosphere and Oceans, edited by: Hoboken, N. J., John Wiley, p. 154, 1978.

Keene, W. C., Sander, R., Pszenny, A. A. P., Vogt, R., Crutzen, P. J., and Galloway, J. N.: Aerosol pH in the marine boundary layer: A review and model evaluation, J. Aerosol Sci., 29, 339-356, 1998.

Knipping, E. M. and Dabdub, D.: Impact of chlorine emissions from sea-salt aerosol on coastal urban ozone, Environ. Sci. Technol., 37, 275-284, 2003.

Levasseur, M., Gosselin, M., and Michaud, S.: A new source of dimethylsulfide (DMS) for the Arctic atmosphere: Ice diatoms, Mar. Biol., 121, 381-387, 1994.

Li, S. M., Barrie, L. A., and Sirois, A.: Biogenic sulfate aerosol in the Arctic troposphere, 2, Trends and seasonal variation, J. Geophys. Res., 98, 20623-20631, 1993.

Lowenthal, D. H. and Rahn, K. A.: Regional sources of pollution aerosol at Barrow, Alaska during winter 1979-1980 as deduced from elemental tracers, Atmos. Environ., 19, 2011-2024, 1985.

Mason, B.: Principles of Geochemistry, Wiley and Sons, New York, 1966.

Nordenskiöld, A. E.: Nordenskiöld on the inland ice of Greenland, Science, 2, 732-739, 1883.
O’Dwyer, J., Isaksson, E., Vinje, T., Jauhiainen, T., Moore, J., Pohjola, V., Vaikmae, R., and van de Wal, R. S. W.: Methanesulfonic acid in a Svalbard ice core as an indicator of ocean climate, Geophys. Res. Lett., 27, 1159-1162, 2000.

Pacyna, J. M., Semb, A., and Hanssen, J. E.: Emission and longrange transport of trace elements in Europe, Tellus, 36B, 163178, 1984.

Platt, U., Allan, W., and Lowe, D.: Hemispheric average $\mathrm{Cl}$ atom concentration from ${ }^{13} \mathrm{C} /{ }^{12} \mathrm{C}$ ratios in atmospheric methane, Atmos. Chem. Phys., 4, 2393-2399, 2004, http://www.atmos-chem-phys.net/4/2393/2004/.

Pszenny, A. A. P., Keene, W. C., Jacob, D. J., Fan, S., Maben, J. R., and Zetwo, M. P.: Evidence of inorganic $\mathrm{Cl}$ gases other than hydrogen chloride in marine surface air, Geophys. Res. Lett., 20, 699-702, 1993.

Quinn, P. K., Miller, T. L., Bates, T. S., Ogren, J. A., Andrews, E., and Shaw, G. E.: A 3-year record of simultaneously measured aerosol chemical and optical properties at Barrow, Alaska, J. Geophys. Res., 107(D11), 4130, doi:10.1029/2001JD001248, 2002.

Quinn, P. K., Coffman, D. J., Kapustin, V. N., Bates, T. S., and Covert, D. S.: Aerosol optical properties in the marine boundary layer during ACE 1 and the underlying chemical and physical aerosol properties, J. Geophys. Res., 103, 16547-16563, 1998.

Quinn, P. K., Shaw, G., Andrews, E., Dutton, E. G., Ruoho-Airola, T., and Gong, S. L.: Arctic haze: Current trends and knowledge gaps, Tellus, 59B, 99-114, 2007.

Raatz, W. E. and Shaw, G. E.: Long-range tropospheric transport of pollution aerosols into the Alaskan Arctic, J. Clim. Appl. Meteorol., 23, 1052-1064, 1984.

Rahn, K. A.: The $\mathrm{Mn} / \mathrm{V}$ ratio as a tracer of large-scale sources of pollution aerosol for the Arctic, Atmos. Environ., 15, 14571464, 1981.

Rahn, K. A. and McCaffrey, R. J.: On the origin and transport of the winter Arctic Aerosol, Annu. N. Y. Acad. Sci., 338, 486-503, 1980.

Rahn, K. A. and Shaw, G. E.: Sources and transport of Arctic pollution aerosol: A chronicle of Six years of ONR research, Nav. Res. Rev., 4-26, 1980.

Sen, P. K.: Estimates of the regression coefficient based on Kendall's tau, J. Am. Stat. Assoc., 63, 1379-1389, 1968.

Stern, D. I.: Global sulfur emissions from 1850 to 2000, Chemosphere, 58, 163-175, 2005.

Zoller, W. H., Gordon, G. E., Gladney, E. S., and Jones, A. G.: The sources and distribution of vanadium in the atmosphere, in: Trace Elements in the Environment, Adv. in Chem. Series, No. 123, ACS, Washington DC, pp. 31-47, 1973. 